\title{
YURISDIKSI PENGADILAN TERHADAP TINDAK PIDANA UMUM YANG MELIBATKAN MILITER DAN SIPIL
}

\author{
Mia Kusuma Fitriana \\ Fakultas Hukum Universitas 17 Agustus 1945 \\ J1. Ir. H. Juanda No.80 Samarinda \\ Email: miakusuma2001@yahoo.com
}

\begin{abstract}
The writing of this research was backgounded by the incident happened in Cebongan Prison. Where detainees were being murdered by some Military personel. This case being a national issued since the incident happened between Civilian and Military Personel. In which the victims are the Civilians and the perpetrator are Military Personels. Thus the jurisdiction of the trial becoming the new issue. Since the perpetrator who came from Military shall be prosecuted within Military Trial. Meanwhile the victims are civilians means this case shall belong to Public Trial.

Therefore occur a thought whereas the Trial should belong to Connectivity Trial. Indeed this trial has a jurisdiction in between Military and Public Trial. Connectivity trial is a trial system applies towards criminal acts whereas the suspects were attributive between civilian and military personel. Although at the end this belong to the Military Trial this research will analyze deeper of how the Public, Military and Connectivity Trial works. Thus there will be a better uderstanding relates to the legality of Military Trial in this case.

The methods being used in this research is descriptive and analyze qualitatively. The Data resources are taken from either national and local newspapers, national news portals as well. Study literature in this reseach are taken from National Laws, The book of criminal law, and The Book of Criminal Law Procedure.

Based on the literature studies can be concluded that Military Trial has only jurisdiction towards criminal acts did by the Military Personel who violates military criminal law, meanwhile Public Trial has jurisdiction over military personel did criminal acts within general criminal law. In a case of a person conducting general criminal acts and military criminal act in the same time then the case will belong to Connectivity Trial.
\end{abstract}

Key words: military trial, public trial, connectivity trial, court jurisdiction

\begin{abstract}
Abstrak
Penulisan ini dilatarbelakangi oleh perkembangan kasus penyerangan dan pembunuhan terhadap tahanan titipan Kepolisian di Lembaga Pemasyarakatan Cebongan beberapa waktu lalu. Terdapat tarik ulur kepentingan baik mengenai penanganan kasus ini, terutama mengenai kewenangan lembaga peradilan yang berwenang untuk mengadili kasus tersebut. Mengingat korban adalah warga sipil, sedangkan tersangka pelaku penembakan adalah personel militer. Yang mana jurisdiksi lembaga peradilan diantara korban dan pelaku berbeda. Sebagai warga sipil menjadi kewenangan Pengadilan Negeri, sedangkan personel militer merupakan kewenangan Pengadilan Militer.

Oleh karenanya muncul wacana penyelesaian melalui Peradilan Koneksitas. Yaitu suatu sistem peradilan yang diterapkan atas suatu tindak pidana dimana diantara tersangkanya terjadi
\end{abstract}


penyertaan antara penduduk sipil dengan anggota militer. Walaupun pada akhirnya kasus ini menjadi kewenangan dari Pengadilan Militer, akan tetapi akan di telaah lebih lanjut bilamana pengunaan Pengadilan Umum, Pengadilan Militer, dan Pengadilan Koneksitas. Sehingga terdapat pemahaman yang jelas sekaligus menelaah ke-sahihan kewenangan Pengadilan Militer dalam Kasus Penyerangan dan Pembunuhan di LP Cebongan.

Metode yang digunakan dalam penulisan ini adalah metode deskriptif dengan bentuk penilaian kualitatif. Sumber data yang diperoleh yaitu dari beberapa surat kabar nasional maupun lokal, dan portal berita nasional . Penelitianini menggunakan penelitian kepustakaan atau Literature Study yang di dapatkan dari undang-undang, Kitab Undang-undang Hukum Pidana dan Kitab Undang-undang Hukum Acara Pidana.

Berdasarkan hasil penelitianpustaka dapat disimpulkan bahwaPeradilan militer hanya memiliki kewenangan atas tindak pidana militer yang dilakukan oleh Prajurit TNI yang melanggar ketentuan hukum pidana militer sedangkan pengadilan umum memiliki kewenangan mengadili tindak pidana yang dilakukan prajurit militer yang melakukan kejahatan sebagaimana dimaksud dalam ketentuan pidana umum. Dalam hal seseorang melakukan tindak pidana umum dan sekaligus di dalamnya terdapat tindak pidana militer, maka menjadi tindakan ini menjadi kewenangan peradilan umum melalui mekanisme koneksitas.

Kata kunci: lapas cebongan, yurisdiksi pengadilan, pembunuhan

\section{Latar belakang}

Pada Sabtu, 23 Maret 2013, belasan orang menyerbu penjara Cebongan, Sleman, Yogyakarta, dengan menggunakan senjata laras panjang, pistol, dan granat. Penyerang menembak mati empat tahanan titipan Kepolisian Daerah Yogyakarta, yaitu Hendrik Angel Sahetapi alias Deki, 31 tahun, Yohanes Juan Manbait (38), Gameliel Yermianto Rohi Riwu alias Adi (29), dan Adrianus Candra Galaja alias Dedi (33). ${ }^{1}$ Peristiwa penyerangan dan pembunuhan ke empat Tahanan titipan Polda DIY yang merupakan warga sipil di Lembaga Pemasyarakatan (LP) Cebongan Sleman yang terjadi pada tanggal 23 Maret lalu masih menjadi permasalahan hangat hingga saat ini.
Berdasarkan keterangan pers dari Wakil Komandan Polisi Militer, Brigadir Jenderal TNI, Unggul Yudhoyono diungkapkan adanya 11 anggota Kopassus Grup 2 Kandang Menjangan, Kartosuro, Sukoharjo, Jawa Tengah terlibat dalam aksi penembakan itu. ${ }^{2}$ Kasus penyerangan dan pembunuhan tersebut menjadi perhatian khusus khalayak. Banyak kalangan menyayangkan peristiwa ini, karena penyerangan dan pembunuhan terjadi di Lembaga Pemasyarakatan yang seharusnya menjadi tempat yang aman bagi Tahanan maupun Terpidana dalam menjalanan vonis pengadilan. Dengan adanya kejadian ini maka sempat menimbulkan keresahan bagi para tahanan dan atau narapidana yang masih berada di dalam LP.

1 Kronologi Pengeroyokan Anggota Kopassus Sertu Heru, http://www.jpnn.com/read/2013/03/23/164068/ Kronologi-Pengeroyokan-Anggota-Kopassus-Sertu-Heru-, diakses 10 September 2013 pukul 10.10 WIB.

2 Ananda Badudu, Penyerang Cebongan Anggota Kopassus, http://www.tempo.co/read/ news/2013/04/04/063471236/Penyerang-Cebongan-Anggota-Kopassus, diakses 10 September 2013 pukul 20.19 WIB. 
Setelah teka-teki pelaku penyerangan terjawab, kini muncul perdebatan seputar kewenangan pengadilan atas kasus ini. Pihak TNI telah menegaskan bahwa 11 pelaku penyerangan akan disidang di pengadilan militer. Namun, keputusan ini ditentang oleh kalangan LSM. Sedangkan Kepala Dinas Penerangan TNI AD Brigjen TNI Rukman Ahmad menyatakan sikap tegas bahwa merujuk peraturan perundang-undangan yang berlaku, beliau bersikeras peradilan militer yang bisa digunakan dalam menyidik pelaku yang merupakan anggota Kopassus Grup 2 Kandang Menjangan, Kartosuro, Solo. Rukman memastikan bahwa penyidik Polri tidak akan berperan dalam proses hukum ini. Peradilan militer, sepenuhnya ditangani oleh internal TNI. Beliau menegaskan bahwa kontribusi Polri hanyalah sebatas menyerahkan data hasil investigasi mereka dalam kasus Cebongan. ${ }^{3}$ Panglima TNI Laksamana Agus Suhartono mengatakan bahwa undang-undang yang mengamanatkan pada peradilan militer untuk penyelesaian sebagaimana kasus LP Cebongan, maka beliau mengikuti peraturan perundangan yang ada, sehingga pengadilan militer lah yang akan diterapkan dalam kasus Cebongan. $^{4}$
Sementara terdapat desakan dari beberapa pengamat militer untuk menggunakan peradilan umum karena perbuatan pidana umum yang dilakukan oleh anggota Kopassus. Terdapat perbedaan pendapat dari beberapa ahli hukum dengan pendapat pengamat militer. Beberapa ahli hukum berpendapat bahwa menurut konstitusi, kasus Cebongan memang seharusnya diadili di Pengadilan Militer tetapi jika melihat objek perkaranya, termasuk tindak pidana umum sehingga seharusnya disidangkan di Peradilan Umum. ${ }^{5}$

Sebagai sebuah proses penegakan hukum, persidangan yang digelar dalam pengadilan militer merupakan aturan baku apabila ada personel militer yang melakukan tindak pidana. Bahkan, undang-undang telah menentukan apabila ada anggota militer yang bersama warga sipil melakukan sebuah tindak pidana maka persidangannya digelar pada peradilan umum. Namun, ada kalangan yang berpendapat perlunya perubahan yang mendasar dalam proses peradilan terhadap personel militer yang melakukan kejahatan atau tindak pidana umum dan korbannya adalah warga sipil, maka seyogianya persidangan dilakukan di peradilan umum.

3 Indra Wijaya, Kasus Cebongan, TNI AD Tolak Peradilan Koneksitas, http://www.tempo.co/read/ news/2013/04/08/063471983/Kasus-Cebongan-TNI-AD-Tolak-Peradilan-Koneksitas, diakses 10 September 2013 pukul 20.50 WIB.

4 Prihandoko, Panglima TNI: Peradilan Militer di Kasus Cebongan, http://www.tempo.co/read/ news/2013/04/08/063471936/Panglima-TNI-Peradilan-Militer-di-Kasus-Cebongan, diakses 10 September 2013 pukul 21.59 WIB.

5 Administrator, CHA: Kasus Cebongan seharusnya disidang di Peradilan Umum, http://www.komisiyudisial. go.id/berita-5032-cha-kasus-cebongan-seharusnya-disidang-di-peradilan-umum.html,diakses 10 September 2013 pukul 22.10 WIB. 
Dalam beberapa hari setelah kejadian tersebut terungkap, terdapat beberapa wacana untuk melaksanakan pengadilan koneksitas terhadap 11 anggota Kopassus Grup 2 Kandang Menjangan, Kartosuro, Sukoharjo, Jawa Tengah terlibat dalam aksi penembakan tersebut. Wacana ini didasarkan pada pertimbangan hukum yang merujuk pada UU No 8 Tahun 1981 tentang Hukum Acara Pidana, menyebutkan bahwa tindak pidana yang dilakukan bersama-sama oleh mereka yang termasuk lingkungan peradilan umum dan lingkungan peradilan militer, diperiksa dan diadili oleh pengadilan dalam lingkungan peradilan umum kecuali jika menurut Keputusan Menteri Pertahanan dan Keamanan dengan persetujuan Menteri Kehakiman perkara itu harus diperiksa dan diadili oleh pengadilan dalam lingkungan peradilan militer. ${ }^{6}$ Mengutip rumusan Pasal 90 Ayat (1) UU No 8 Tahun 1981 maka, untuk menentukan peradilan mana yang berwenang mengadili kasus tersebut, maka jaksa atau jaksa tinggi dan oditur militer atau oditur militer tinggi melakukan penelitian bersama.

Pro dan kontra terjadi, argumentasi yang digunakan mereka yang menghendaki agar Peradilan Militer hanya untuk pelanggaran pidana militer adalah dalam sebuah negara yang demokratis harus ada supremasi sipil. Oleh karena itu pelanggaran pidana umum yang dilakukan oleh personil militer harus tunduk kepada kewenangan dan otoritas sipil.
Terlepas dari perkara pidana yang sangat nyata, sebenarnya kasus penyerangan dan pembunuhan ini sangat menarik untuk di telaah. Hal ini dikarenakan keterlibatan oknum militer dalam tindakan pidana pembunuhan terhadap warga sipil.

Penelaahan lebih lanjut terhadap lembaga pengadilan mana yang seharusnya paling kompeten untuk mengadili kasus ini akan sangat menarik. Menilik kasus tersebut merupakan kasus dimana oknum militer di dakwa melakukan pembunuhan terhadap warga sipil, sedangkan kewenangan pengadilan terhadap warga sipil dan militer mempunyai yurisdiksi yang berbeda.

Dalam tulisan ini, penulis tidak akan membahas lebih lanjut terhadap perkara pidana pembunuhan atau penyerangan. Tetapi penulis akan membahas lebih lanjut terhadap kewenangan atau Yurisdiksi Pengadilan yang menangani kasus yang mana terdapat keterlibatan Militer dan Sipil. Sudah diketahui bahwa untuk mengadili perkara dalam kasus hukum warga sipil adalah yurisdiksi dari Pengadilan Umum, sedangkan untuk mengadili perkara dalam kasus hukum militer (prajurit) adalah yurisdiksi dari Pengadilan Militer. Atau bahkan dimungkinkannya yurisdiksi Peradilan Koneksitas atas kasus tersebut berdasarkan atas argumentasi hukum yang ada.

Metode yang digunakan dalam penulisan ini adalah metode deskriptif dengan bentuk

6 Pasal 89 ayat 1 Undang-undang Nomor 8 tahun 1981 tentang Kitab Undang-undang Hukum Acara Pidana. 
penilaian kualitatif. Sumber data yang diperoleh yaitu dari beberapa surat kabar nasional maupun lokal, dan portal berita nasional. Penelitian ini menggunakan penelitian kepustakaan atau Literature Study yang di dapatkan dari undang-undang, Kitab Undang-undang Hukum Pidana dan Kitab Undang-undang Hukum Acara Pidana.

Oleh karena itu kajian lebih lanjut adalah mengenai pembedaan yurisdiksi pengadilan yang tepat untuk mengadili kasus-kasus serupa Cebongan yang mana para pihak yang terlibat adalah Militer dan Sipil. Pengadilan umum atau pengadilan militer atau bahkan pengadilan koneksitas yang tampak sahih secara hukum nasional terhadap kasus serupa kasus LP Cebongan ini.

\section{Pembahasan}

Tindak pidana adalah suatu perbuatan yang dilakukan manusia yang dapat bertanggung jawab yang mana perbuatan tersebut dilarang atau diperintahkan atau dibolehkan oleh undang-undang yang diberi sanksi berupa sanksi pidana. ${ }^{7}$ Subyek dari tindakan pidana umum adalah masyarakat sipil, akan menjadi suatu kekhususan adalah apabila militer sebagai pelaku tindakan pidana. Atau dapat juga diartikan sebagai pelanggaran pidana umum yang dilakukan oleh milliter. Sedangkan kewenangan peradilan bagi sipil dan militer adalah berbeda.

Kewenangan badan peradilan untuk memeriksa, mengadili, dan memutus suatu perkara; sebagaimana diketahui berdasarkan Pasal 10 UU 48/2009 tentang Kekuasaan Kehakiman terdapat 4 (empat) lingkungan peradilan, yakni; peradilan umum, peradilan agama, peradilan militer, dan peradilan tata usaha negara. Hal ini berkaitan dengan Kewenangan Absolut Peradilan.

Oleh karena itu Berdasarkan Kompetensi Absolute suatu Peradilan di bedakan menjadi; 1. Kompetensi Absolut Dari Peradilan Umum adalah memeriksa, mengadili, dan memutuskan perkara pidana yang dilakukan oleh orang-orang sipil dan perkara perdata, kecuali suatu peraturan perundang-undangan menentukan lain (Pasal 50 UU 2/1986 tentang Peradilan Umum).

2. Kompetensi Absolut Dari Peradilan Agama adalah memeriksa, mengadili, dan memutuskan perkara-perkara orang yang beragama Islam dalam bidang perkawinan, warisan, wasiat, hibah, waqaf, dan shadaqah (Pasal 49 UU No 50/2009 tentang Peradilan Agama).

3. Kompetensi Absolut Dari Peradilan Militer adalah mengadili tindak pidana yang dilakukan oleh seorang yang pada waktu melakukan adalah Prajurit; yang berdasarkan undang-undang dipersamakan dengan prajurit; anggota suatu golongan atau jawatan atau badan atau yang dipersamakan atau dianggap sebagai prajurit berdasarkan undangundang; seseorang yang tidak termasuk

7 Erdianto Effendi, Hukum Pidana Indonesia (Suatu Pengantar), Refika Aditama, Bandung, 2011, hlm. 100. 
prajurit atau yang ber-dasarkan undangundang dipersamakan dengan prajurit atau anggota suatu golongan atau jawatan atau badan atau yang dipersamakan atau dianggap sebagai prajurit ber-dasarkan undang-undang; tetapi atas keputusan Panglima dengan persetujuan Menteri Kehakiman harus diadili oleh suatu Pengadilan dalam lingkungan peradilan militer.(Pasal 9 UU 31/1997 tentang Peradilan Militer).

4. Kompetensi absolut dari Peradilan Tata Usaha Negara adalah memeriksa, mengadili, dan memutuskan sengketa yang timbul dalam bidang tata usaha negara antara seseorang atau badan hukum perdata dengan badan atau pejabat tata usaha negara akibat dikeluarkannya suatu keputusan tata usaha negara, termasuk sengketa kepegawaian (Pasal 1 ayat 4 UU 09/2004) dan tidak dikeluarkannya suatu keputusan yang dimohonkan yang dimohonkan seseorang sampai batas waktu yang ditentukan dalam suatu peraturan perundang-undangan, sedangkan hal itu telah merupakan kewajiban badan atau pejabat tata usaha negara yang bersangkutan (Pasal 3 UU 09/2004 tentang Peradilan Tata Usaha Negara).

Kompetensi Absolute inilah yang menjadi dasar kajian Kewenangan atau Yurisdiksi atas suatu perkara yang mana para pihak yang terlibat di dalamnya adalah sipil dan militer.
Bilamana suatu perkara yang melibatkan sipil dan militer akan menjadi yurisdiksi Peradilan Umum, atau Peradilan Militer? Hal ini dikarenakan salah satu pihak berperkara adalah Militer sedangkan pihak lawan adalah sipil. Atau bahkan dimungkinkan perkara tersebut masuk ke dalam Yurisdiksi Peradilan Koneksitas.

Berikut adalah kajian berdasarkan kewenangan masing-masing Peradilan di tilik dari Peraturan Perundang-undangan maupun pelaku dan atau korban dalam suatu tindak pidana yang melibatkan Sipil dan Militer dalam satu kasus yang sama.

\section{A. Peradilan Militer}

Ketentuan mengenai yurisdiksi peradilan militer yang ada hubungannya dengan subjek tindak pidana (kejahatan dan pelanggaran) dan masuk kekuasaan kehakiman dalam peradilan ketentaraan adalah sebagai berikut: ${ }^{8}$

1. Seorang yang pada waktu itu adalah anggota angkatan perang.

2. Seorang yang pada waktu itu adalah orang yang dengan undang-undang atau dengan peraturan pemerintah ditetapkan sama denagn Angkatan Perang Republik Indonesia yang dimaksudkan dalam sub a

3. Seorang yang pada waktu itu adalah anggota suatu golongan atau jawatan yang dipersamakan atau dianggap sebagai anggota Angkatan Perang Republik Indonesia oleh atau berdasarkan undangundang. 
4. Seorang yag tidak termasuk golongan a, b, dan c tetapi atas ketetapan Menteri Pertahanan dengan persetujuan Menteri Kehakiman harus diadili oleh suatu pengadilan dalam lingkungan peradilan ketentaraan.

Setelah diundangkannya Undang-Undang Nomor 31 Tahun 1997 tentang Peradilan Militer, ketentuan mengenai yustisiabel dan yurisdiksi peradilan militer disebutkandalam undang-undang tersebut bahwa pengadilan dalam lingkungan peradilan militer berwenang:9

1. Mengadili tindak pidana yang dilakukan oleh seseorang yang pada waktu melakukan tindak pidana adalah: Prajurit; Yangberdasarkanundang-undang dipersamakan dengan Prajurit;Anggota suatu golongan atau jawatan atau badan atau yang dipersamakan atau dianggap sebagai Prajurit berdasarkan undangundang;Seseorang yang tidak masuk golongan pada huruf a, huruf $b$, dan huruf c tetapi atas keputusan Panglima dengan persetujuan Menteri Kehakiman harus diadili oleh suatu Pengadilan dalam lingkungan peradilan militer.

2. Memeriksa, memutus, dan menyelesaikan sengketa Tata Usaha Angkatan Bersenjata.

3. Menggabungkan perkara gugatan ganti rugi dalam perkara pidana yang bersangkutan atas permintaan dari pihak yang dirugikan sebagai akibat yang ditimbulkan oleh tindak pidana yang menjadi dasar dakwaan, dan sekaligus memutus kedua perkara tersebut dalam satu putusan.

Dilihat dari kemandirian peradilan militer dan hukum pidana militer, seseorang dapat merupakan (ditentukan) sebagai yustisiabel peradilan militer, tetapi tidak selalu dapat menjadi subjek dari suatu tindak pidana militer. Sebaliknya seseorang yang dapat melakukan tindak pidana militer selalu merupakan yustisiabel peradilan militer.

Berdasarkan undang-undang ini, maka semua peraturan, undang-undang yang berkaitan dengan Peradilan Militer maupun hukum acaranya dinyatakan tidak berlaku. Undang-Undang ini selain mengatur tentang susunan dan kekuasaan pengadilan serta oditurat (kejaksaan) di lingkungan Peradilan Militer juga memuat hukum acara pidana militer. Hal yang paling baru yang belum pernah diatur sebelumnya adalah masalah sengketa Tata Usaha ABRI dan menggabungkan perkara gugatan ganti rugi dalam perkara pidana. Pengadilan dalam lingkungan Peradilan Militer terdiri dari: ${ }^{10}$

1) Pengadilan Militer;

2) Pengadilan Militer Tinggi;

3) Pengadilan Militer Utama; dan

4) Pengadilan Militer Pertempuran.

9 Undang-undang Nomor 31 Tahun 1997 Loc.cit., Pasal 9.

10 Ibid., Pasal 12. 
Kekuasaan Pengadilan Militer, Pengadilan Militer Tinggi dan Pengadilan MiliterUtama hampir sama dengan kekuasaan pengadilan sebagaimana diatur dalam ketentuan sebelumnya, hanya ditambahkan dengan sengketa Tata Usaha dan menggabungkan gugatan ganti rugi. Sedangkan Pengadilan Militer Utama, sebelumnya Mahkamah Militer Agung dengan kekuasaan hampir sama, hanya ditambahkan kekuasaan untuk memutus perbedaan pendapat antar Perwira Penyerah Perkara dan Oditur berkaitan dengan diajukannya perkara kepengadilan. Sedangkan Pengadilan Militer Pertempuran memiliki kekuasaan memeriksa Pidana oleh prajurit (militer) di daerah pertempuran serta bersifat mobil mengikuti gerakan pasukan, berkedudukan serta berdaerah hukum di daerah pertempuran ${ }^{11}$ pidana yang dilakukan oleh prajurit ABRI atau yang dipersamakan berdasarkan undang-undang atau seseorang yang berdasarkan Keputusan Panglima dengan persetujuan Menteri Kehakiman harus diadili oleh pengadilan militer juga memeriksa, memutus dan menyelesaikan sengketa Tata Usaha Angkatan Bersenjata serta menggabungkan perkara gugatan ganti rugi dalam perkara pidana dalam satu putusan.

Undang-undang Nomor. 31 tahun 1997 tentang Peradilan Militer selain mengatur susunan, organisasi peradilan juga mengatur hukum acaranya, hukum acara yang diatur dalam Undang-undang ini hampir sama dengan Undang-undang Nomor 8 Tahun 1981 tentang Hukum Acara Pidana dengan berbagai kekhususan, seperti kewenangan Komandan (Atasan yang Berhak menghukum/Ankum) melakukan penyidikan, penahan serta peran Perwira Penyerah Perkara dalam penyerahan perkara. $^{12}$

\section{B. Peradilan Koneksitas}

Pengertian Koneksitas menurut arti kata berasal dari bahasa latin Connexio yang berarti adanya suatu hubungan dalam bertindak,yang dalam arti hukum yaitu perkara pidana yang di periksa oleh pengadilan dalam lingkungan peradilan umum terhadap mereka yang bersama-sama melakukan tindak pidana yang termasuk dalam lingkungan peradilan umum dan peradilan militer, kecuali jika kerugian yang ditimbulkan oleh delik tersebut terletak pada kepentingan militer, maka segera diadili oleh peradilan militer. ${ }^{13}$

Sedangkan pengertian koneksitas yang ditegaskan dalam KUHAP Pasal 89 adalah yurisdiksi suatu peradilan terhadap tindak pidana yang dilakukan bersama-sama oleh mereka yang termasuk lingkungan peradilan umum dan lingkungan peradilan militer, diperiksa dan di adili oleh pengadilan dalam lingkungan peradilan umum kecuali jika menurut keputusan Menteri Pertahanan dan Keamanan dengan persetujuan Menteri 
Kehakiman perkara itu harus diperiksa dan di adili oleh pengadilan dalam lingkungan peradilan militer.

Peradilan koneksitas adalah suatu sistem peradilan yang diterapkan atas suatu tindak pidanadimana diantara tersangkanya terjadi penyertaan antara penduduk sipil dengan anggota militer. Menurut Prof Andi Hamzah yang dimaksud dengan peradilan koneksitas adalah sistem peradilan terhadaptersangka pembuat delik penyertaan antara orang sipil dengan orang militer. ${ }^{14}$

Sehingga sudah pasti bahwa peradilan koneksitas menyangkut delik penyertaan antara yang dilakukan orang sipil bersama orang militer.Prof Andi Hamzah berpendapat bahwa di dalam peradilan koneksitas selalu terjadi penyertaan antara penduduk sipil dengan orang militer. 15

Dari pengertian di atas dapatlah kita lihat bahwa yang menjadi permasalahan pokok di dalam peradilan koneksitas adalah mengenai yuridiksi mana yang berwenang untuk mengadili perkara yang melibatkanpenyertaan antara penduduk sipil dengan anggota militer.

Koneksitas adalah mekanisme hukum acara untuk mengadili tindak pidana yang perkaranya dicakup oleh kewenangan dua peradilan yakni Peradilan Militer dan Peradilan Umum, khususnya tindak pidana yang memenuhi unsur-unsur tindak pidana yang secara paralel diatur dalam hukum pidana militer dan umum.

Dasar hukum yang paling pokok peradilan koneksitas adalah Undang-undang Nomor 14 tahun 1970 tentang Ketentuan Pokok Kekuasaan Kehakiman, yang dinyatakan bahwa: ${ }^{16}$

“Tindak pidana yang dilakukan
bersama-sama oleh mereka yang
termasuk lingkungan peradilan
umum dan lingkungan peradilan
militer diperiksa dan diadili oleh
pengadilan dalam lingkungan
peradilan umum, kecuali kalau
menurut keputusan Menteri
Pertahanan/Keamanan dengan
persetujuan Menteri Kehakiman
perkara itu harus diperiksa dan
diadili oleh pengadilan dalam
lingkungan peradilan militer."

Selain itu juga di jelaskan dalam KUHAP, apabila terjadi sebuah peristiwa pidana yang dilakukan secara bersama-sama oleh warga sipil yang secara hukum berada dalam lingkungan peradilan umum dengan anggota Tentara Nasional Indonesia (TNI) dan Kepolisian Republik Indonesia (POLRI) yang secara hukum berada dalam lingkungan peradilan militer, ${ }^{17}$ maka akan menjadi kewenangan Pengadilan Koneksitas.

\footnotetext{
14 Andi Hamzah, Hukum Acara Pidana Indonesia, Sinar Grafika, Jakarta, 2006, hlm. 214.

15 Ibid.

16 Pasal 22 Undang-undang Nomor 14 Tahun 1970 tentang Ketentuan-ketentuan Pokok Kekuasaan Kehakiman yang Diperbaharui oleh Undang-undang Nomor 35 Tahun 1999.

17 Pasal 89 ayat 1 KUHAP.
} 
Untuk menetapkan pengadilan mana yang akan mengadili di atur dalam Pasal 90 KUHAP yaitu, untuk menetapkan apakah pengadilan dalam lingkungan peradilan militer atau pengadilan dalam lingkungan peradilan umum yang akan mengadili perkara pidana sebagaimana dimaksud dalam Pasal 89 Ayat (1), dia adakan penelitian bersama oleh jaksa atau jaksa tinggi dan oditur militer atau oditur milter tinggi atas dasar hasil penyelidikan tim tersebut pada Pasal 89 Ayat (2).

Sebuah perkara koneksitas itu diperiksa dan diadili oleh lingkungan Peradilan Militer itu diatur dalam ketentuan pasal 90 KUHAP. Yang mana dijelaskan bahwa untuk menentukan apakah lingkungan peradilan militer yang berwenang memeriksa dan mengadili suatu perkara koneksitas, diukur dari segi kerugian yang ditimbulkan oleh tindak pidana itu. Apabila kerugian yang ditimbulkan oleh sebuah tindak pidana tersebut lebih memberikan kerugian terhadap "kepentingan militer", sekalipun pelaku tindak pidananya lebih banyak dari kalangan masyarakat sipil, pemeriksaan perkara koneksitas akan dilakukan oleh lingkungan peradilan militer. Selama kerugian yang ditimbulkan oleh tindak pidana yang terjadi tidak merugikan kepentingan militer, sekalipun pelakunya lebih banyak anggota TNI/Polri, maka perkara koneksitas diperiksa dan diadili oleh lembaga peradilan umum.
KUHAP telah menentukan cara dan aparat yang berwenang dalam melakukan penyidikan terhadap perkara koneksitas. Aparat penyidik perkara koneksitas terdiri dari suatu "tim tetap", yang terdiri atas unsur: ${ }^{18}$

a. Unsur Penyidik Polri;

b. Polisi Militer;

c. Oditur Militer atau Oditur Militer Tinggi

Cara bekerja tim disesuaikan dengan kewenangan yang ada pada masing-masing unsur tim. Bila dilihat dari segi wewenang masing-masing unsur tim ${ }^{19}$, maka:

a. Tersangka pelaku sipil diperiksa oleh unsur penyidik Polri.

b. Sedangkan tersangka pelaku anggota TNI/Polri diperiksa oleh penyidik dari Polisi Militer dan Oditur Militer.

Susunan Majelis Hukum peradilan perkara koneksitas disesuaikan dengan lingkungan peradilan yang mengadili perkara tersebut: ${ }^{20}$

a. Apabila perkara koneksitas diperiksa dan diadili oleh lingkungan peradilan umum, maka susunan Majelis Hakimnya adalah:

- Sekurang-kurangnya Majelis Hakim terdiri dari tiga orang.

- Hakim Ketua diambil dari Hakim Peradilan Umum (Pengadilan Negeri).

- Hakim Anggota ditentukan secara berimbang antara lingkungan peradilan umum dengan lingkungan peradilan militer. 
b. Apabila perkara koneksitas diperiksa dan diadili oleh lingkungan Peradilan Militer, maka susunan Majelis Hakimnya adalah:

- Hakim Ketua dari lingkungan Peradilan Militer.

- Hakim Anggota diambil secara berimbang dari hakim Peradilan Umum dan Peradilan Militer.

- Hakim Anggota yang berasal dari lingkungan Peradilan Umum diberi pangkat militer "tituler".

Yang mengusulkan Hakim Anggota adalah Menteri Hukum dan Hak Asasi Manusia bersama dengan Menteri Pertahanan. Susunan ini juga berlaku pada susunan Majelis Hakim pada tingkat Banding.

Dalam hal melakukan upaya paksa penangkapan dan penahanan dalam suatu tindak pidana umum yang melibatkan pelaku militer, Polisi Militer wajib membantu Kepolisian. Kejaksaan memiliki kewenangan penuh untuk melakukan penuntutan dalam suatu tindak pidana umum yang melibatkan pelaku militer. Dalam hal Polisi Militer sebagai penyidik tindak pidana kemiliteran mengetahui telah terjadi pula tindak pidana umum yang dilakukan oleh pelaku militer maka Polisi Militer wajib menyerahkan kepada pihak Kepolisian.

Tindak pidana umum yang dilakukan oleh militer berlaku ketentuan penyelidikan dan penyidikan serta penuntutan di dalam KUHAP.
Pelibatan Polisi Militer dalam penyidikan tindakan pidana umum yang dilakukan oleh prajurit dilakukan apabila polisi memerlukan upaya paksa, termasuk, tapi tidak terbatas pada, tindakan penangkapan, penahanan, penggeledahan, penyitaan dan pemeriksaan surat.

\section{Peradilan Umum}

Pengadilan adalah pengadilan negeri dan pengadilantinggi di lingkungan peradilan umum. $^{21}$ Pengadilan umum meliputi ,Pengadilan Negeri, berkedudukan di ibukota kabupaten/kota, dengan daerah hukum meliputi wilayah kabupaten / kota bertugas utk memeriksa dan memutuskan perkara tinggkat pertama dari segala perkara sipil untuk semua golongan penduduk (warga negara dan orang asing). Peradilan umum berwenang memeriksa, mengadili, dan memutus perkara pidana dan perdata. $^{22}$ Pengadilan sebagai mana dimaksud dalam UU nomor 49 Tahun 2009 adalah pengadilan negeri dan pengadilan tinggi di lingkungan peradilan umum. ${ }^{23}$

Pengadilan negeri adalah suatu pengadilan (umum) yang memeriksa dan memutuskan perkara tingkat pertama dari segala perkara sipil untuk semua golongan penduduk (warga negara dan orang asing). Setiap perkara dalam pengadilan negeri diadili oleh sekurangkurangnya tiga orong hakim yang dibantu oleh seorang panitera. Perkara-perkara ringan

21 Pasal 1 Ayat 1 Undang-undang Nomor 49 Tahun 2009 tentang Perubahan Kedua atas Undang-undang Nomor 2 Tahun 1986 tentang Peradilan Umum.

22 Pasal 25 ayat (2), jo ayat (3) s/d ayat (5) UU No. 48 Tahun 2009 tentang Kekuasaan Kehakiman.

23 Ibid., Pasal 1 ayat 1. 
yang ancaman hukuman kurang dari satu tahun diadili oleh seorang hakim (hakim tunggal) daerah hukum pengadilan negeri pada dasarnya meliputi daerah kabupaten/ kota. $^{24}$

Dengan demikian, pengadilan negeri berwenang memeriksa dan memutuskan sesuatu perkara perdata atau pidana yang terjadi dalam wilayah daerah kabupaten/ kotayang menjadi kekuasaannya. Berkaitan dengan hal ini, pengadilan negeri memiliki kewenangan nisbi, kewenangan nisbi adalah kewenangan untuk memeriksa gugatan atas tuntutan berdasarkan tempat tinggal tergugat.

Pengadilan negeri dipimpin oleh seorang kepala beserta seorang wakil kepala, beberapa orang hakim yang dibantu oleh seorang panitera, beberapa orang panitera pengganti, sekretaris, dan juru sita. Panitera diangkat dan diberhentikan oleh menteri kehakiman, sedangkan panitera pengganti diangkat dan diberhentikan oleh kepala pengadilan yang bersangkutan. Panitera bertugas memimpin bagian administrasi atau tata usaha. Ia dibantu oleh wakil panitera, beberapa panitera pengganti, dan karyawan-karyawan lainnya. Juru sita bertugas melaksanakan semua perintah yang diberikan oleh ketua sidang, menyampaikan pengumuman-pengumuman, teguran-teguran, memberitahukan putusan pengadilan, dan melakukan penyitaan.
Pada setiap pengadilan negeri ditempatkan kejaksaan negeri yang terdiri atas seorang atau lebih jaksa dan jaksa-jaksa muda. daerah kekuasaan kejaksaan sama dengan daerah kekuasaan pengadiln negeri. Kejaksaan adalah alat pemerintah yang bertindak sebagai penuntut umum dalam suatu perkara pidana terhadap pelanggaran hukum pidana(bertindak untuk mempertahankan kepentingan umum).

Berikut alur penyelesaian perkara pidana di Pengadilan Umum:

Kompetensi peradilan umum, khususnya dalam perkara pidana akan diproses melalui sistem peradilan pidana yang dimulai dari proses penyidikan, penuntutan, pengadilan dan lembaga pemasyarakatan. Dalam perkara pidana terdakwanya selama ini berasal dari kalangan rakyat sipil (di dalamnya termasuk terdakwa yang berasal dari polri) atau bisa dari kalangan rakyat sipil dan kalangan militer (perkara koneksitas). ${ }^{25}$

\section{Yurisdiksi Pengadilan dalam Kasus yang melibatkan Sipil dan Militer}

Melihat dari paparan diatas, setidaknya kita telah dapat membedakan yurisdiksi pengadilan umum, pengadilan militer maupun pengadilan koneksitas. Walaupun pada akhirnya telah diputuskan bahwa yurisdiksi pengadilan atas kasus LP Cebongan adalah

24 Pasal 4 Undang-undang Nomor 8 Tahun 2004 tentang Perubahan UU Nomor 2 Tahun 1986 tentang Peradilan Umum.

25 Rezafaraby, Kedudukan dan Peran Peradilan Militer di Indonesia, http://stasiunhukum.wordpress. com/2010/05/10/kedudukan-dan-peran-peradilan-militer-di-indonesia/, diakses 18 September 2013 pukul 12.10 WIB. 


\section{Gambar 1. Alur Penyelesaian Perkara Pidana di Pengadilan Umum}
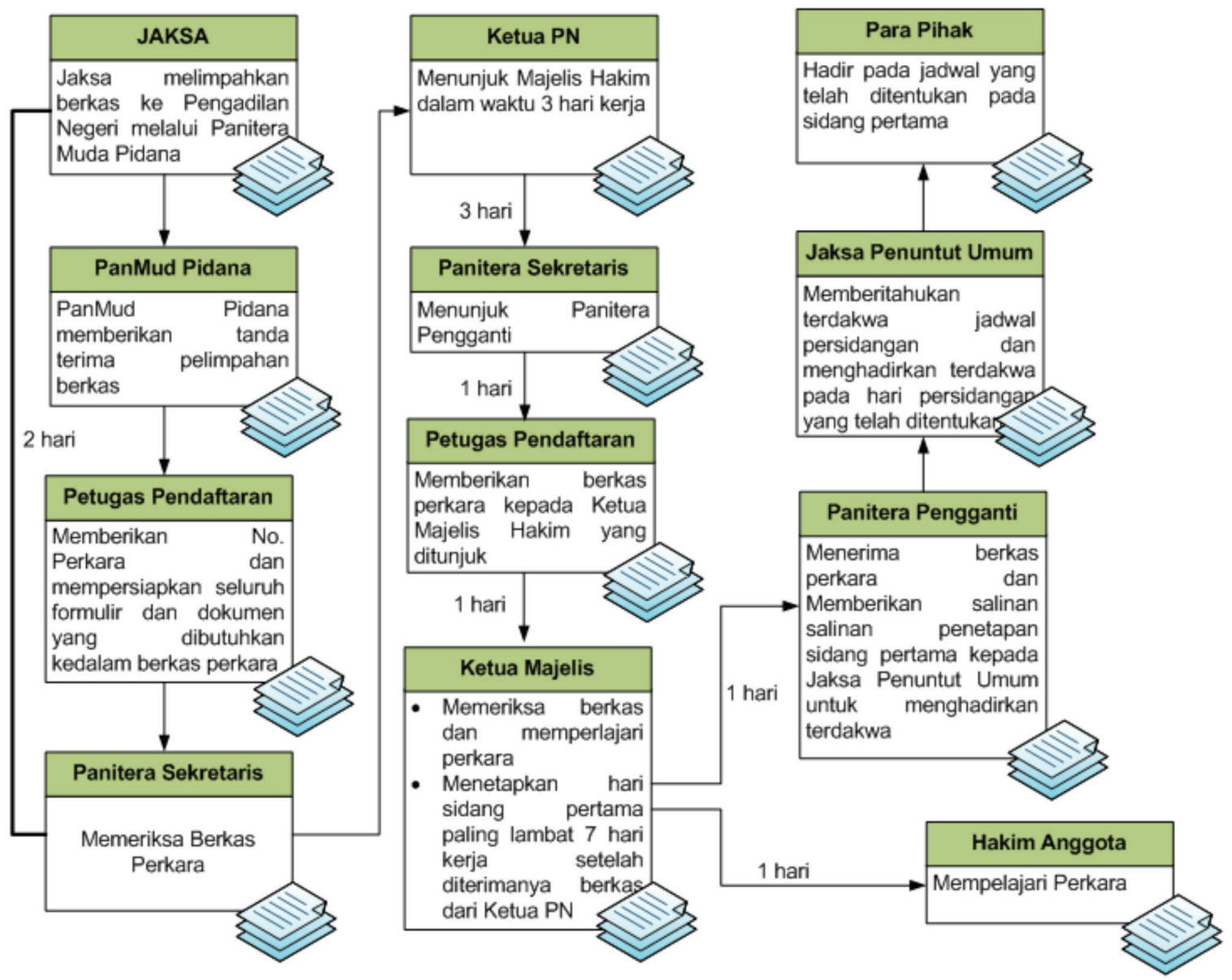

Sumber: http://www.pn-medankota.go.id/v2/index.php/panitera/pidana/alur-pidana

Pengadilan Militer, akan tetapi akan kita kaji lebih lanjut mengenai legitimasi dari Peradilan Militer terhadap Kasus Penyerangan LP Cebongan.

Menurut Undang-undang Nomor 31 Tahun 1997, peradilan militer merupakan pelaksana kekuasaan kehakiman di lingkungan angkatan bersenjata untuk menegakkan hukum dan keadilan dengan memperhatikan kepentingan penyelenggaraan pertahanan keamanan negara.

Pengadilan dalam lingkungan peradilan militer berwenang: Mengadili tindak pidana yang dilakukanoleh seseorangyang padawaktu melakukan tindak pidana adalah Prajurit, yang berdasarkan undang-undang dipersamakan dengan prajurit, anggota suatu golongan atau jawatan atau badan yang dipersamakan atau dianggap sebagai prajurit berdasarkan undang-undang, seseorang yang tidak masuk golongan prajurit/yang dipersamakan dengan prajurit dan dianggap sebagai prajurit tetapi atas putusan panglima dengan persetujuan menteri kehakiman harus diadili oleh suatu pengadilan dalam lingkungan peradilan militer.

Dalam kasus penyerangan LP Cebongan, tersangka pelaku penyerangan sekaligus 
pembunuhan terhadap tahanan titipan pidana umum. Penyerangan dan pembunuhan Kepolisian adalah para oknum Komando merupakan tindak pidana umum sebagai mana Pasukan Khusus (Koppasus) yang masih aktif bertugas. Yang mana sesuai dengan yurisdiksi Peradilan Militer yang dijelaskan dalam kewenangan absolut dari Peradilan Militer yaitu untuk memeriksa dan memutus perkara pidana yang terdakwanya adalah anggota TNI dengan pangkat tertentu. Dengan demikian benar bahwa pengadilan militer diperuntukkan bagi seseorang yang pada waktu melakukan tindak pidana adalah Prajurit.

Sebagaimana pemaparan diatas, Yurisdiksi Peradilan Militer terhadap pelaku Penyerangan dan Pembunuhan Tahanan di LP Cebongan adalah benar sampai dengan ketentuan perundang-undangan belum mengatur perubahan mengenai kewenangan Peradilan Militer. Sebagaimana tercantum dalam UU No. 34 Tahun 2004 tentang TNI (UU TNI) yang menyatakan bahwa Prajurit tunduk kepada kekuasaan peradilan militer dalam hal pelanggaran hukum pidana militer dan tunduk pada kekuasaan peradilan umum dalam hal pelanggaran hukum pidana umum yang diatur dengan undang-undang.

Membahas tindak pidana umum acuan yang disimak adalah Kitab UndangUndang Hukum Pidana dan ketentuan yang merubahnya (mencabut, merubah dan menambah), semua tindak pidana yang termaktub di dalam Kitab Undang-Undang Hukum Pidana (KUHP) merupakan tindak diatur dalam KUHP termasuk pada kejahatan terhadap nyawa ${ }^{26}$ bahkan mengakibatkan kematian.

Tindak pidana penyerangan LP Cebongan dan Pembunuhan 4 tahanan Polda adalah masuk ke ranah KUHP kejahatan terhadap nyawa. Melihat dari jenis kejahatan yang menjadi cakupan KUHP maka menurut ketentuan jenis tindak pidana ini menjadi kewenangan Peradilan Umum (Pengadilan Negeri/Tinggi). Akan tetapi apabila di lihat dari pelaku kejahatan yaitu prajurit, maka akan terbelah kajian yuridis antara tindak pidana berdasarkan kejahatan yang dilakukan ataukah pelaku kejahatan.

Ditilik dari tindak pidananya, maka kejadian ini menjadi kompetensi peradilan umum. Akan tetapi menilik ketentuan Peradilan Militer yang diperuntukkan bagi kalangan militer maka kasus seperti ini dapat menjadi kewenangan Peradilan Militer. Undang-undang tentang TNI menyatakan bahwa bagi prajurit yang melakukan pelanggaran militer harus tunduk pada kekuasaan militer, akan tetapi apabila prajurit militer melakukan pelanggaran hukum pidana umum sebagaimana terdapat dalam ketentuan KUHP maka seharusnyalah tunduk pada peradilan umum.

Berdasarkan tindak pidana yang dilakukan oleh secara yuridis kasus ini seharusnya 
menjadi kewenangan Peradilan Umum. tahun 1986 yang di rubah menjadi UU Nomor Akan tetapi perlu di ingat bahwa Tap MPR Ketetapan No. VI/MPR/2000 dan Ketetapan No. VII/MPR/2000 yang telah memisahkan POLRI dari angkatan bersenjata (TNI), sekaligus menundukkan prajurit TNI dan anggota POLRI kepada hukum dan prosedur peradilan pidana umum belum dapat di laksanakan. Karena sampai sekarang revisi mengenai yurisdiksi Peradilan Militer itu belum terjadi, maka di mata hukum, peradilan militer memang masih memiliki yurisdiksi atas kasus-kasus seperti di LP Cebongan.

Begitu pula UU TNI juga mengisyaratkan bahwa pelaksanaan Pengadilan Umum bagi prajurit yang melakukan tindak pidana umum belum dapat dilaksanakan sampai adanya revisi mengenai yurisdiksi peradilan militer. Sebagaimana kompetensi peradilan militer adalah untuk memeriksa dan memutus perkara pidana yang terdakwanya adalah anggota TNI dengan pangkat tertentu. Undang-undang Peradilan Militer inilah yang merupakan Lex Specialis , sehingga sepanjang tidak dilakukan perubahan UU Peradilan Militer, maka tindak pidana umum yang terdakwanya adalah Prajurit TNI akan tetap menjadi Yurisdiksi Peradilan Militer.

Dan perkara seperti ini bukanlah menjadi yurisdiksi dari Peradilan Koneksitas maupun Peradilan Umum. Kasus Penyerangan dan Pembunuhan Tahanan di LP Cebongan bukanlah merupakan Yurisdiksi dari Peradilan Umum dikarenakan kewenangan absolut dari pengadilan umum yaitu berdasarkan UU no 2 49 Tahun 2009 tentang Peradilan Umum menyebutkan bahwa kewenangan pengadilan umum yaitu memeriksa dan memutus perkara dalam hukum pidana (umum dan khusus) dan perdata (umum dan niaga). Sementara kompetensi yurisdiksi absolute dari Peradilan Militer secara nyata adalah untuk memeriksa dan memutus perkarapidanayang terdakwanya adalah anggota TNI dengan pangkat tertentu.

Kasus ini juga bukan merupakan yurisdiksi dari Peradilan Koneksitas. Hal ini dikarenakan dalam peradilan koneksitas unsur kerugian yang menjadi perhatian utama. Apabila kerugian yang ditimbulkan oleh sebuah tindak pidana tersebut lebih memberikan kerugian terhadap "kepentingan militer", sekalipun pelaku tindak pidananya lebih banyak dari kalangan masyarakat sipil, pemeriksaan perkara koneksitas akan dilakukan oleh lingkungan peradilan militer. Selama kerugian yang ditimbulkan oleh tindak pidana yang terjadi tidak merugikan kepentingan militer, sekalipun pelakunya lebih banyak anggota TNI/Polri, maka perkara koneksitas diperiksa dan diadili oleh lembaga peradilan umum.

Dengan demikian yurisdiksi pengadilan milter dalm kasus ini adalah sah, terlepas dari segala kontroversi politis dan hal lain yang menyertainya, akan tetapi yurisdiksi absolute dari Pengadilan Militer untuk memeriksa dan memutus perkara pidana yang terdakwanya adalah anggota TNI dengan pangkat tertentumerupakan ketentuan yang valid untuk dilaksanakan. 


\section{Simpulan}

Adanya tindak pidana yang melibatkan unsur sipil dan militer baik dalam hal subyek maupun tindak pidana yang menyebabkan terjadinya konflik yurisdiksi (tumpang tindih kewenangan mengadili) sehingga dapat menimbulkan ketidakpastian hukum. Peradilan militer hanya memiliki kewenangan atas tindak pidana militer yang dilakukan oleh Prajurit TNI yang melanggar ketentuan hukum pidana militer sedangkan pengadilan umum memiliki kewenangan mengadili tindak pidana yang dilakukan prajurit militer yang melakukan kejahatan sebagaimana dimaksud dalam ketentuan pidana umum.

Dalam hal seseorang melakukan tindak pidana umum dan sekaligus di dalamnya terdapat tindak pidana militer, maka menjadi tindakan ini menjadi kewenangan peradilan umum melalui mekanisme koneksitas. Akan tetapi menilik kewenangan absolut Peradilan Militer yang tegas dinyatakan dalam Nomor 31 Tahun 1997 tentang Peradilan Militer bahwa Peradilan Militer mempunyai yurisdiksi absolut atas sebuah kasus yang mana terdakwa adalah Militer merupakan Lex Specialis yang tidak dapat dilanggar sampai dengan adanya perubahan hukum yang mengatur. Apabila sudah terdapat perubahan hukum yang menguatkan Tap MPR Ketetapan No. VI/ MPR/2000 dan Ketetapan No. VII/MPR/2000 dan UU TNI maka kasus serupa LP Cebongan akan menjadi Yurisdiksi Peradilan Umum.

\section{DAFTAR PUSTAKA}

\section{Buku}

Effendi, Erdianto, 2011, Hukum Pidana

Indonesia (Suatu Pengantar), Refika Aditama, Bandung.

Hamzah, Andi, 2006, Hukum Acara Pidana

Indonesia, Sinar Grafika, Jakarta.

Sumaryanti, 1987, Peradilan Koneksitas di

Indonesia, cetakan Ke-1, Bima Aksara, Jakarta.

\section{Peraturan Perundang-undangan}

Kitab Undang-undang Hukum Pidana.

Kitab Undang-undang Hukum Acara Pidana.

Kitab Undang-undang Hukum Pidana Militer.
Undang-undang Nomor 5 Tahun 1950 tentang Peradilan Militer yang diperbaharui oleh Undang-undang Nomor 31 Tahun 1997 tentang Peradilan Militer.

Undang-undang Nomor 14 Tahun 1970 tentang Ketentuan-ketentuan Pokok Kekuasaan Kehakiman yang diperbarui oleh Undang-undang Nomor 35 Tahun 1999.

Undang-undang Nomor 8 tahun 1981 tentang

Kitab Undang-undang Hukum Acara Pidana.

Undang-undang Nomor 2 Tahun 1986 tentang Peradilan Umum. 
Undang-undang Nomor 31 Tahun 1997 Naskah Internet tentang Peradilan Militer.

Kronologi Pengeroyokan Anggota

Undang-undang Nomor 9 Tahun 2004 tentang

Peradilan Tata Usaha Negara.

Undang-undang Nomor 34 Tahun 2004 tentang Tentara Nasional Indonesia.

Undang-undang Nomor 50 tahun 2009 tentang Peradilan Agama.

Undang-undang Nomor 48 Tahun 2009 tentang Kekuasaan Kehakiman.

Undang-undang Nomor 49 Tahun 2009 tentang Perubahan Kedua Atas Undang-undang Nomor 2 Tahun 1986 tentang Peradilan Umum.

Kopassus Sertu Heru, http://www. jpnn.com/read/2013/03/23/164068/ Kronologi-Pengeroyokan-AnggotaKopassus-Sertu-Heru-.

Ananda Badudu, Penyerang Cebongan Anggota Kopassus, http://www.tempo. co/read/news/2013/04/04/063471236/ Penyerang-Cebongan-AnggotaKopassus.

Indra Wijaya, Kasus Cebongan, TNI AD Tolak Peradilan Koneksitas, h t t p :// w w w.te m po.co/read/ news/2013/04/08/063471983/KasusCebongan-TNI-AD-Tolak-PeradilanKoneksitas. 